\title{
Effect of Vermicompost on Growth of Coconut Seedlings under Field Conditions in Sri Lanka
}

\author{
S.H.S. Senarathne ${ }^{1}$
}

\begin{abstract}
Organic matter contributes in maintaining soil fertility in agriculture. Vermicompost is rich in plant nutrients and recognized as potential organic manure source for many crops. In this experiment, different amount of vermicompost and inorganic fertilizers were tested. The objective of the research was to evaluate the effect of vermicompost on the growth of coconut seedling in the field conditions and to reduce the cost of production of coconut plantations. Treatments were arranged in a Randomized Complete Block Design (RCBD) with three replicates. The experiment consisted of three different fertilizer treatments with vermicompost $(100 \%)+$ Dolomite $500 \mathrm{~g}\left(\mathrm{~T}_{1}\right)$, Inorganic fertilizer (Young Palm Mixture) + Dolomite $\left(\mathrm{T}_{2}\right)$ and vermicompost + Inorganic fertilizer (Young Palm Mixture) + Dolomite $\left(\mathrm{T}_{3}\right)$. Growth measurements revealed A significantly higher seedling girth, leaf production rate and early highest coconut seedling flowering percentage in the vermicompost base integrated fertilizer applied treatment when compare with other two treatments. This experiment had brought out that application of vermicompost base integrated fertilizer application system is beneficial for coconut seedlings in the field for the better field establishment and vigorous seedling growth.
\end{abstract}

Key words: Vermicompost, inorganic fertilizer, coconut, shoots growth

Running title: Vermicompost on coconut seedling growth

\section{Introduction}

Due to the global energy crisis the cost of fuel based chemical fertilizers has increased tremendously. Feasibility of usage of artificial fertilizers has become a serious concern to developing countries due to the high cost of fertilizers (Singhe, 1998). In coconut farming systems, high amount of nutrients are removed through the harvest materials and the soil erosion. Long term application of chemical fertilizers also depletes the soil fertility. Therefore, it is essential to supply natural organic manures which would help to increase the soil fertility in coconut farming system.

The use of organic matter such as animal manures, food wastes, yard wastes, sewage sludge and composts has long been recognized in agriculture as beneficial for plant growth and yield and the maintenance of soil fertility. The new approaches to use of organic amendments in farming systemshave proven to be effective means of improving soil structure, enhancing soil fertility and increasing crop yields. Organic matters are excellent source of plant-available nutrients and their addition to soil could maintain high microbial populations and activities (Pascual et al., 1997; Zink and Allen, 1998). The results of several long-term studies have shown that the addition of compost improves soil physical properties by decreasing bulk density and increasing the soil water holding capacity (Weber, 2007). Moreover, in comparison with mineral fertilizers, compost significantly increases soil organic carbon and some plant nutrients (García-Gil, 2000, Bulluck et al., 2002; Nardi et al., 2004; Weber, 2007).

\footnotetext{
${ }^{1}$ Agronomy Division, Coconut Research Institute, Lunuwila, Sri Lanka.

Email: shsumith71@yahoo.com
} 
Composting has been recognized as a low cost and environmentally sound process for treatment of many organic wastes (Hoitink, 1993). Furthermore, the rapid decomposition and raised temperatures during composting produce a relatively homogeneous, odor-free, pathogenfree and easy-to-handle product. Bevacqua and Mellano (1993) reported that compost-treated soils had lower $\mathrm{pH}$ and increased levels of organic matter, primary nutrients, and soluble salts. In crop studies, Bryan and Lance (1991) found that tomatoes grown in compost-amended soils yielded more. Maynard (1993) also reported increases in fruit yield of compostamended plants compared with those growing in soil alone. Other benefits from the use of compost include the possible reduction of hazards from nitrate leaching into groundwater compared to those from inorganically fertilized controls (Maynard, 1989). A process related to composting which can improve the beneficial utilization of organic wastes is vermicomposting. It is a non-thermophilic process by which organic materials are converted by earthworms and microorganisms into rich soil amendments with greatly increased microbial activity and nutrient availability. Earth worms consume and fragment the organic wastes into finer particles by passing them through a grinding gizzard and derive their nourishment from microorganisms that grow upon them. The process accelerates the rates of decomposition of the organic matter, alter the physical and chemical properties of the material, leading to a humification effect in which the unstable organic matter is fully oxidized and stabilized (Albanell et al., 1988; Orozco et al., 1996). The end product, commonly referred to as vermicompost is greatly humified through the fragmentation of the parent organic materials by earthworm sand colonization by microorganisms (Edwards and Neuhauser, 1988).

Optimum plant growth and development is important for greater final dry matter and yields of any crops. In order to achieve this purpose, sufficient amounts of nutrients should be applied to the soil through inorganic and organic sources. Vermicompost for example, an organic source of plant nutrients, contains a higher percentage of nutrients necessary for plant growth in readily available forms (Theunissen et al., 2010). There is also evidence that humic acids extracted from vermicompost stimulated in increasing the number of roots, giving the plant ability to scavenge nutrient from the growing environment for growth and development (Alvarez et al., 1995). In this experiment, vermicompost and vermicompost with inorganic fertilizers were tested. The objective of the research was to evaluate the effect of vermicompost on the growth of coconut seedling in the field conditions and to reduce the cost of production of coconut plantations.

\section{Materials and Methods}

This experiment was carried out at the Iriyagolla Estate, Pannala, Sri Lanka which is located in the Intermediate Zone Low Country ( $\mathrm{IL}_{1}$ a) from 2008 to 2013. The area is characterized by bimodal pattern of rainfall with an annual mean precipitation of $>1700 \mathrm{~mm}$. Approximately $60 \%$ and $40 \%$ of the annual rainfall are received during March to May (Yala) and September to November (Maha) respectively. A high ambient air and soil temperature $\left(24^{0} \mathrm{C}-29^{0} \mathrm{C}\right)$ bright sunshine hours (about 6-8 hours day ${ }^{-1}$ ) are more common during the dry periods of May to September and $4-7$ hours day ${ }^{-1}$ during the rainy periods. The soil at the site is Red Yellow Podzolic (RYP) (USDA soil taxonomy - Typic Rhodudults) (FAO/ UNESCO soil taxonomy - Ferric Altisols) soils with soft and hard laterites. Soils are very deep and well drained. Surface soil is dark yellowish brown in colour with a gravely sandy clay loam texture. The sub surface soil is strong brown in colour and texture ranges from gravely sandy clay loam to gravely clay loam. The structure of the surface soil is a moderately sub angular blocky and sub-surface is moderate to strong sub angular blocky. Reaction of the soil is slightly acidic (pH 4.0 - 4.5) throughout the soil profile. Base saturation is greater than $35 \%$ and deceases with soil depth. Cation Exchange Capacity of the soil increases with soil depth and ranges from $3-4$ cmol $_{C} \mathrm{Kg}^{-1}$ and the dominant basic cation is Ca. Organic matter percentage is $1.34 \%$ and sand, silt and clay percentages are 54.45, 10.06 and $35.49 \%$ respectively (Mapa et al., 
2005). In coconut plantations, there are large numbers of plant species which produce large quantities of biomass. Therefore, these resources can be used for the production of vermicompost. However, nutrient contents of the vermicompost change with the materials which are used for composting process. Tithoniadiversifolia, Puereriaphasioloides, and Gliricidiasepium biomasses were used to produce vermicompost for the study.

The experiment was established in newly established uniform coconut seedling block. All the coconut seedlings were well managed by following the recommended practices. Weed control was done manually. Pest and disease incidences were controlled. Experimental treatments were arranged in a Randomized Complete Block Design (RCBD) with three replicates. The experiment consisted of three different fertilizer treatments with Vermicompost $(100 \%)+$ Dolomite $500 \mathrm{~g}\left(\mathrm{~T}_{1}\right)$, Inorganic fertilizer (Young Palm Mixture) + Dolomite $\left(\mathrm{T}_{2}\right)$ and Vermi-compost + Inorganic fertilizer (Young Palm Mixture) + Dolomite $\left(\mathrm{T}_{3}\right)$, were measured and add to the coconut seedling manure circle and mixed well with the manure circle soil. All the treatments were added according to the following table.

\section{Shoot measurements}

Seedling girth $(\mathrm{cm})$ was measured using measuring tape at the point of shoot emergence from the nut at six month interval and the number of new leaf production was counted at twelve months interval.

\section{Data analysis}

Experimental data were analysed following Analysis of Variance (ANOVA) procedure using the statistical software SAS (SAS reference) and the significance of the differences between means was tested using Least Significant Differences (LSD) at $\mathrm{P}=0.05$ (SAS Institute 1999).

\section{Results and Discussion}

This study was intended to assess the impact of vermicompost base fertilizer mixtures on the growth of coconut seedlings in the field condition. During the experimental period, coconut seedling girth $(\mathrm{cm})$ was measured at six month interval. The leaf production rate (number of leaves produce per year) and percentage of flowering seedlings were measured at annually. The girth of coconut seedlings grown with different fertilizer mixtures were not significantly different $(\mathrm{P}<0.05)$ during the first 2.5 years (Table 2 ).

In the third year, significantly greater seedling girth was observed in the vermicompost base treatments $\left(T_{1} \& T_{3}\right)$ that was significantly different from only inorganic fertilizer applies treatment $\left(\mathrm{T}_{2}\right)$. Atiyeh et al., (2002a) reported greater growth of Tomato seedlings treated with vermicompostprobably as a result of combined improved physical conditions and nutritional factors of soil.

The rate of leaf production were not significantly different $(\mathrm{P}<0.05)$ during the first four years of the experimental period (Table 3 ). However, from fourth year, coconut seedlings grown with vermicompost with inorganic fertilizer $\left(T_{3}\right)$ treatment had a significantly higher leaf production rate when compared with other two treatments. To maintain a quality coconut plantation selection of quality seedling with good girth, growth and higher number of opened leaves is very important. Coconut seedlings grown with vermicompost and inorganic fertilizer together means integrated fertilizer application method always showed greater seedling girth and leaf production rate compared to seedling growth without following integrated fertilizer application system. Some field experiments have involved amending soils with vermi-composts in combination with recommended inorganic fertilization programs. Vermi-composts applied to field soils together with recommended application rate of inorganic fertilizers increased yields of Okra (Abelmoschusesculentus Moench) significantly (Ushakumari et al., 1999). Amending soils with vermicomposts with recommended rate of inorganic fertilizers, promoted shoot production of bananas (Athani et al., 1999).

Integrated fertilizer application treatment (vermi-compost with inorganic fertilizer) 
Table 1. Treatment application plan with age of the coconut seedlings

\begin{tabular}{|c|c|c|c|c|c|c|c|c|c|c|}
\hline Treatments & Ingredients & $\begin{array}{c}\text { Basal } \\
\text { mixture }\end{array}$ & $\begin{array}{c}0.5 \\
\text { year }\end{array}$ & $\begin{array}{c}1 \\
\text { year }\end{array}$ & $\begin{array}{c}1.5 \\
\text { year }\end{array}$ & $\begin{array}{c}2 \\
\text { year }\end{array}$ & $\begin{array}{c}2.5 \\
\text { year }\end{array}$ & $\begin{array}{c}3 \\
\text { year }\end{array}$ & $\begin{array}{c}3.5 \\
\text { year }\end{array}$ & $\begin{array}{c}4 \\
\text { year }\end{array}$ \\
\hline \multirow[b]{2}{*}{$\mathrm{T}_{1}$} & Vermicompost (kg) & 20 & 10 & 12 & 12 & 16 & 16 & 20 & 20 & 24 \\
\hline & Dolomite (kg) & 1000 & 500 & 500 & 500 & 500 & 500 & 500 & 500 & 500 \\
\hline \multirow{4}{*}{$\mathrm{T}_{2}$} & Urea $(g)$ & 250 & 150 & 180 & 180 & 24 & 240 & 300 & 300 & 360 \\
\hline & E.R.P (g) & 750 & 340 & 405 & 405 & 540 & 540 & 675 & 675 & 810 \\
\hline & M.O.P. (kg) & 250 & 150 & 180 & 180 & 240 & 240 & 300 & 300 & 360 \\
\hline & Dolomite (kg) & 1000 & 500 & 500 & 500 & 500 & 500 & 500 & 500 & 500 \\
\hline \multirow{5}{*}{$\mathrm{T}_{3}$} & Vermicompost (kg) & 12 & 6 & 8 & 8 & 12 & 12 & 15 & 15 & 20 \\
\hline & Urea $(\mathrm{g})$ & 125 & 75 & 90 & 90 & 120 & 120 & 150 & 150 & 180 \\
\hline & E.R.P (g) & 375 & 170 & 200 & 200 & 270 & 270 & 340 & 340 & 405 \\
\hline & M.O.P. (kg) & 125 & 70 & 90 & 90 & 120 & 120 & 150 & 150 & 180 \\
\hline & Dolomite (kg) & 1000 & 500 & 500 & 500 & 500 & 500 & 500 & 500 & 500 \\
\hline
\end{tabular}

E.R.P. - Eppawala Rock Phosphate / M.O.P - Muriate of Potash

Table 2. Effect of different fertilizer treatments on coconut seedling girth $(\mathrm{cm})$

\begin{tabular}{|c|c|c|c|c|c|c|c|c|c|c|}
\hline \multirow{2}{*}{ Treatments } & \multicolumn{9}{|c|}{ Time } \\
\cline { 2 - 11 } & $\mathbf{2 0 0 7}$ & \multicolumn{2}{|c|}{$\mathbf{2 0 0 8}$} & \multicolumn{2}{|c|}{$\mathbf{2 0 0 9}$} & \multicolumn{2}{|c|}{$\mathbf{2 0 1 0}$} & \multicolumn{2}{|c|}{$\mathbf{2 0 1 1}$} & $\mathbf{2 0 1 2}$ \\
\cline { 2 - 11 } & Dec & June & Dec & June & Dec & June & Dec & June & Dec & June \\
\hline $\mathrm{T}_{1}$ & 28 & 37 & 56 & 80 & 98 & 106 & 123 & 144 & 152 & 156 \\
$\mathrm{~T}_{2}$ & 21 & 34 & 41 & 72 & 88 & 94 & 104 & 118 & 138 & 142 \\
$\mathrm{~T}_{3}$ & 24 & 30 & 57 & 77 & 89 & 108 & 116 & 132 & 154 & 160 \\
Significance & $\mathrm{ns}$ & $\mathrm{ns}$ & $\mathrm{ns}$ & $\mathrm{ns}$ & $\mathrm{ns}$ & $*$ & $*$ & $*$ & $*$ & $*$ \\
LSD (P<0.05) & - & - & - & - & - & 8 & 10 & 9 & 11 & 8 \\
\hline
\end{tabular}

* Significantly different at $\mathrm{P}=0.05$; ns- not significant

Table 3. Effect of different fertilizer treatments on leaf production rate (number of leaves produce per month)

\begin{tabular}{|c|c|c|c|c|c|c|c|}
\hline \multirow{2}{*}{ Treatments } & \multicolumn{9}{|c|}{ Time (Years) } \\
\cline { 2 - 8 } & $\mathbf{2 0 0 7}$ & $\mathbf{2 0 0 8}$ & $\mathbf{2 0 0 9}$ & $\mathbf{2 0 1 0}$ & $\mathbf{2 0 1 1}$ & $\mathbf{2 0 1 2}$ & $\mathbf{2 0 1 3}$ \\
\hline $\mathrm{T}_{1}$ & 0.98 & 0.80 & 0.76 & 0.92 & 0.86 & 0.94 & 0.82 \\
$\mathrm{~T}_{2}$ & 0.97 & 0.75 & 0.79 & 1.01 & 0.87 & 0.96 & 0.97 \\
$\mathrm{~T}_{3}$ & 1.01 & 0.75 & 0.72 & 0.98 & 0.98 & 1.12 & 1.19 \\
Significance & $\mathrm{ns}$ & $\mathrm{ns}$ & $\mathrm{ns}$ & $\mathrm{ns}$ & $*$ & $*$ & $*$ \\
LSD $(\mathrm{P}<0.05)$ & & & & - & 0.08 & 0.11 & 0.18 \\
\hline
\end{tabular}

* Significantly different at $\mathrm{P}=0.05$; ns- not significant 
Table 4. Effect of different fertilizer treatments on flowering percentage (\%) of coconut seedlings

\begin{tabular}{|c|c|c|c|c|c|c|c|}
\hline \multirow{2}{*}{ Treatments } & \multicolumn{7}{|c|}{ Time (Years) } \\
\cline { 2 - 8 } & $\mathbf{2 0 0 7}$ & $\mathbf{2 0 0 8}$ & $\mathbf{2 0 0 9}$ & $\mathbf{2 0 1 0}$ & $\mathbf{2 0 1 1}$ & $\mathbf{2 0 1 2}$ & $\mathbf{2 0 1 3}$ \\
\hline $\mathrm{T}_{1}$ & - & - & - & 10 & 25 & 40 & 75 \\
$\mathrm{~T}_{2}$ & - & - & - & - & 10 & 20 & 45 \\
$\mathrm{~T}_{3}$ & - & - & - & 30 & 60 & 90 & 100 \\
\hline
\end{tabular}

showed early highest coconut seedling flowering percentage when compare with only vermincompost and only inorganic fertilizer application treatments (Table 4). The available nutrient status of soil was greatly enhanced by the application of vermicompost as an organic source (Prabba et al., 2007). Vermicompost enhanced $\mathrm{P}$ concentration and uptake in soil, increasing the solubilization of $\mathrm{P}$ either by microorganism's activation with excretion of organic acids like citric, glutamic, tartaric, succinic, lactic, oxalic, malic and fumaric (Subba Roa, 1982). Basker et al., (1992) reported that the increase in $\mathrm{K}$ uptake by vermicompost application may be due to enhancement in $\mathrm{K}$ availability by shifting the equilibrium among the forms of $\mathrm{K}$ from relatively exchangeable $\mathrm{K}$ to soluble $\mathrm{K}$ forms in the soil (Jordao et al., 2006).

Furthermore, the application of vermicompost in the field enhance the quality of soils by increasing microbial activity and microbial biomass which are key components in nutrient cycling system, production of plant growth regulators and protecting plants soilborne diseases and arthropod pest attack.

\section{Conclusion}

It is suggested that vermicompost base integrated fertilizer application system is more favorable for better coconut seedling establishment in the field. Therefore, integrated use of chemical fertilizer and vermicomposts the best approach for achieving higher crop yields and economic feasibility. In order to address soil fertility problems, potential synergies can be gained by combining technical options with farmers' knowledge as well as training of farmers and development agents on integrated soil fertility management approaches.

\section{References}

Albanell, E., Plaixats, J. and Cabrero, T. 1988. Chemical changes during vermincomposting (Eiseniafetida) of sheep manure mixed with cotton industrial wastes. Biology and Fertility of Soils, 6: 266-269.

Alvarez, M.A.B., Gagne, S. and Antoun, H. 1995. Effect of compost on rhizospheremicroflora of the tomato and on the incidence of plant growthpromoting rhizobacteria. App. Environ. Microbial, 61, 194-199.

Athani, S.I., Hulamanai, N.C., and Shirol, A.M., 1999. Effect of vermicomposts on the maturity and yield of banana. South Indian Horticulture, 47: 1-6, 4-7.

Atiyeh, R.M., Arangon, N.Q., Edwards, C.A. and Metzger. J., 2002a. The influence of earth-worm processed pig manure on the growth and yield of green house tomatoes. Bioresour. Technol., 84(1): 7-14.

Basker, A., Macgregor, A.N. and Kirkman, J.H., 1992. Influence of soil ingestion by earthworms on the availability of potassium in soil: an incubation experiment. Biol. Fertil. Soils, 14(4), 300303.

Bevacqua, R.F. and Mellano, V. 1993. Sewage sludge compost's cumulative effects on crop growth and soil properties.Compost Science and Utilization. Spring 1993: 3437. 
Bryan, H.H. and Lance, C.J. 1991. Compost trials on vegetables and tropical crops. Biocycle 32: 36-37.

Bulluck, L.R, Brosius, M., Evanylo, G.K. and Ristaino, J.B. 2002. Organic and synthetic fertility amendments influence soil microbial, physical and chemical properties on organic and conventional farms. Applied Soil Ecology, 19, 147-160.

Edwards, C.A. and Neuhauser, E.F. 1988. Earthworms in Waste and Environmental Management, SPB Acad. Publ., The Hague, The Netherlands.

Garcia-Gil, J.C., Plaza, C., Soler-Rovira, P. and Polo, A. 2000. Long-term effects of municipal solid waste compost application on soil enzyme activities and microbial biomass. Soil Biology and Biochemistry 32 (13), 1907-1913.

Jordao, C.P., Nascentes, C.C., Cecon, P.R., Fontes, R.L.F. and Pereira, J.L. 2006. Heavy metal availability in soil amended with composted urban solid wastes. Environmental Monitoring and Assessment, 112, 309-326.

Mapa, R.B., Dassanayake, A.R. and Nayakekorale, H.B. 2005. Soils of the Intermediate zone of Sri Lanka: morphology, characterization and classification. Soil Science Society of Sri Lanka, Peradeniya, Sri Lanka.

Maynard A. 1989. Agricultural composts as amendments reduce nitrate leaching. Frontiers of Plant Science 24: 2-4.

Maynard A. 1993. Evaluating the suitability of MSW compost as a soil amendment in field-grown tomatoes. Compost Science and Utilization. Spring 1993: p.34-26

Nardi, S., Morari, F., Berti, A., Tosoni, M. and Giardini, L. 2004. Soil organic matter properties after 40 years of different use of organic and mineral fertilizers. European Journal of Agronomy 21, 357-367.

Orozco, S.H., Cegarra, J., Trujillo, L.M., and Roig, A. 1996. Vermicompostsing of coffee pulp using the earthworm Eiseniafetida: effects on $\mathrm{C}$ and $\mathrm{N}$ contents and the availability of nutrients. Biology and Fertility of Soils. 22: 162-166.

Pascual, J.A., Garcia, C., Hernandez, T. and Ayuso, M. 1997. Changes in the microbial activity of an arid soil amended with urban organic wastes. Biology and Fertility of Soils 24 (4), 429-434.

Prabha, K.P., Loretta, Y.L. and Usha, R.K. 2007. An experimental study of vermi-bio waste composting for agricultural soil improvement. Bio-resources Technology, 99: 1672-1681.

[SAS] Statistical Analysis Systems, 1999. SAS 1, STAT Users Guide, Release, 7.00 Cary, NC: Statistical Analysis Systems Institute, 1028.

Singh, A. 1998. Use of organic material and green manure as fertilizers in developing countries. In organic materials as fertilizers, FAO Soil Bull No. 27, 121.

Subba Rao, N.S., 1982. Utilization of farm wastes and residues in agriculture. In: Subba Rao, N.S. (Ed.), Advances in Agricultural Microbiology. Butterworth Scientific, London, pp. 509-522.

Theunissen, J., Ndakidemi, P. A. and Laubscher, C.P. 2010. Potential of vermicompost produced from plant waste on the growth and nutrient status in vegetable production. International Journal of the Physical Sciences, 5 (13), 1964-1973.

Ushakumari, K., Prabhakumari, P. and Padmaja, P. 1999. Efficiency of vermi compost on growth and yield of summer crop Okra, (Abelmoschusesculentus Moench) Journal of Tropical Agricultural, 37: 87-88.

Weber, J., Karczewska, A., Drozd, J., Licznar, M., Licznar, S., Jamroz, E. and Kocowicz, A. 2007. Agricultural and ecological aspects of a sandy soil as affected by the application of municipal solid waste composts. Soil Biology and Biochemistry, 39, 1294-1302.

Zink, T.A. and Allen, M.F., 1998. The effects of organic amendments on the restoration of a disturbed coastal sage scrub habitat. Restoration-Ecology 6 (1), 52-58. 
Cord 2018, 34 (1) 